\title{
OPEN INNOVATION SYSTEMS IN DEVELOPING COUNTRIES: SUSTAINABLE DIGITAL NETWORKS AND COLLABORATION IN SMES
}

\author{
Petar Vrgović \\ Faculty of Technical Sciences, University of Novi Sad, Serbia \\ vrgovic@uns.ac.rs \\ Ivana Jošanov-Vrgović \\ Novi Sad School of Business, Serbia \\ josanov.vrgovic@gmail.com
}

\begin{abstract}
Small and medium enterprises (SMEs) in developing countries may gain numerous benefits when collaborating with external partners during their innovation projects. Their limitations to innovate independently direct them toward other subjects, with whom collaboration is of mutual interest. However, SMEs in developing countries are also found to face many obstacles while engaging in this kind of relationship, so it is not easy to translate experiences from developed countries into this context. There are many online tools that foster this type of collaboration, but SMEs in developing countries are rarely able to design and maintain this kind of ecosystem on their own. The purpose of this paper is to analyze how SMEs in developing countries may successfully utilize digital networks to collaborate with external partners. The goal of this paper is to provide insights for practitioners in developing countries into how to design and maintain digital networks for open innovation (OI). This paper provides a brief review of contemporary collaboration tools that are effectively used in Ol, which is followed by a review of obstacles that SMEs face when trying to use digital networks. Finally, the paper provides conclusions about the practices that these SMEs could use to collaborate online using appropriate tools.
\end{abstract}

Keywords: open innovation, digital networks, developing countries

\section{INTRODUCTION}

The significance and relevance of innovation as a continuous process is evident across different industries and regions in the world, and it especially has gained significant momentum in the last few decades with economic growth and rapid expansion of new technologies across the globe. There are thousands of peer-reviewed papers in scientific journals, scientific conferences, and practitioners' summits related to innovation, and they are frequently full of buzz-words that emphasize this phenomenon. One particular form of innovation seems specifically popular in the last few decades: open innovation (OI) (Chesbrough, 2003). This type of innovation is defined as "the use of pur- posive inflows and outflows of knowledge to accelerate internal innovation and expand the markets for external use of innovation" (Chesbrough, 2006, p. 1), and it seems to be best suited for companies that want to make the most of their innovation potential. Basically, open innovation means collaborating with external partners during any type of innovation process, in which the result can be inbound or outbound.

In spite being a major economic contributor in most countries around the world, small and medium enterprises (SMEs) frequently face challenges of an inherited nature that make it hard for them to innovate. Unfortunately, SMEs have often been excluded from the mainstream discussion in open innovation re- 
Petar Vrgović, Ivana Jošanov-Vrgović: Open Innovation Systems in Developing Countries: Sustainable Digital Networks and Collaboration in SMEs

search and are just beginning to significantly participate in the open innovation literature (Brunswicker \& van de Vrande, 2014). Furthermore, SMEs frequently have problems keeping up with the innovation pace of the big companies (Rahman \& Ramos, 2014). Therefore, the conclusions that are derived when observing open innovation processes in large companies cannot be easily applied to smaller companies, simply because there is no appropriate organizational structure that could adopt the best practices. Additionally, the contemporary literature often emphasizes the importance of digital technologies and virtual collaboration during innovation projects (Antikainen, Mäkipää, \& Ahonen, 2010), but the literature mostly focuses on online communities and idea-sharing platforms. The literature that examines whether and how SMEs use digital technologies in their innovation projects is scarce.

This paper contributes to the growing literature related to OI in SMEs by identifying basic principles that SMEs should use when they try to virtually network with other subjects in their innovative projects. It is our belief that this is one of the most important steps that SMEs should take when deciding to innovate systematically - to connect with other subjects during their innovation processes. This paper investigates how the SMEs in developing countries can successfully utilize digital networks to collaborate with external partners,

This paper therefore first observes the current state of the literature related to OI in SMEs, especially in developing countries, and then describes the appropriate scenarios that the companies should use. This paper is, by its nature, a conceptual paper that should be perceived as a contribution to the discussion, rather than a definite recipe for innovation success. To contribute to this field, we tap into the potential that digital networks may have for SMEs when it comes to practicing open innovation.

\section{LITERATURE REVIEW}

\subsection{Open innovation in small and medium enterprises}

\subsubsection{Contemporary knowledge about OI in SMEs}

In traditional innovation models, companies keep the innovation process within their boundaries, and it is hard to witness any exchange of knowledge or any collaboration with other subjects. This means that companies need to generate, develop, and market ideas on their own. Because the developmental boundaries of SMEs are quite limited by the nature of the enterprise, and because they often lack any organized internal R\&D, these subjects can gain significant advantages by engaging in collaboration with external subjects. With its inbound and outbound flows (Chesbrough, 2003), open innovation allows SMEs to pursue the strategy to open up the innovation process and to perform innovations by connecting with knowledge that lies outside their own perimeter. This collaboration beyond firm boundaries can take place, for example, with customers, suppliers, research organizations, and universities. In these cases, the exchange of information takes place between different subjects (West \& Bogers, 2014), and in addition to any specific innovations that could be commercialized, companies can also source the very business models that enable such commercialization (Vanhaverbeke, Chesbrough, \& West, 2014).

In the fifteen years since Chesbrough coined the term "open innovation," growing literature about this phenomenon is evident. Chesbrough first started using this term to describe certain behaviors of large companies, and that origin is visible in the fact that most of the literature that followed has also been focused on larger companies. Unfortunately, until recently SMEs were not well represented in the literature and are only starting to frequently appear in this decade. Still, most of the published papers that observed SMEs in the Ol context was mainly based on secondary data or were conceptual or managerial in nature, with few sophisticated statistical analyses (Hossain, 2015; Spithoven, Vanhaverbeke, \& Roijakkers, 2013). The interest in Ol within SMEs has started to grow since it was suggested that small and medium enterprises could benefit to a larger extent than the large companies because they are able to react faster to changing environments, they are generally less burdened by bureaucracy, and they tend to have increased willingness to take risks (Parida, Westerberg, \& Frishammar, 2012).

It is apparent that SMEs depend on their ability to be innovative in order to sustain competitiveness, especially because increased competition, globalization, and rapidly advancing technologies in many in- 
dustries force them to develop new products faster and more effectively. This requirement is most of the times quite challenging for small enterprises because of their size, limited internal resources, and more-restricted competence base (Cooper, Edgett, \& Kleinschmidt, 2003).

Open innovation suggests that SMEs should overcome these obstacles by collaborating with other subjects, thus bringing in more knowledge or taking out surplus technology. For this to happen, SMEs need knowledge and collaboration tools to establish strong connections with their innovation partners. However, SMEs are found to predominantly establish weak ties with other organizations, and they frequently lack ties with larger incumbents; despite significant attempts by regional authorities, the desired robust ties that could spur innovation may be slow to develop (Dodourova \& Bevis, 2014). There is evidence that medium-sized enterprises are more likely to engage in OI than are small enterprises, and for most SMEs the most important motives to participate are market-related: to keep up with market developments and to meet customer demand (van de Vrande, de Jong, Vanhaverbeke, \& de Rochemont, 2009). The same research identified administration-related problems as the dominant obstacles for $\mathrm{OI}$ in these enterprises, rather than lack of time and resources, which was expected.

Finally, even the process of innovation itself is not uniformly observed by the different stakeholders involved. Massa and Testa concluded their paper with this statement: "Traditional innovation indicators, mainly based on inputs or countable outputs, are strongly criticized by the entrepreneurs. The entrepreneurs, affirming that SMEs do not put innovation in the balance sheet, ask for new indicators that are able to measure also the intangible effects of innovation" (2008, p. 404). This warns us to be careful when measuring open innovation activities in SMEs, because there may be problems with content validity.

\subsubsection{SMEs in developing countries}

The traditional innovation process is found to be hard for SMEs in developed countries, so one could hardly imagine this process rolling successfully in developing countries. Indeed, SMEs in developing countries have tried to innovate on their own, but they are faced with numerous internal barriers (lack of time, inadequate $R \& D$, and inadequate financial means) and external obstacles (government market regulation policies, and problems with inputs, access to technology providers, and policies) (Hadjimanolis, 1999; Vrgović, Vidicki, \& Šenk, 2013).

Some of these barriers and obstacles could be eliminated by collaborating with external partners. However, because open innovation frequently exhibits complexity of interplay between technology entrepreneurs and incumbents, and because it may come with high transaction costs (Christensen, Olesen, \& Kjær, 2005), it is additionally challenging for SMEs in developing countries. Barriers such as low competition fairness, access to financing, laws and regulations, and poor support systems are additional obstacles that SMEs in developing countries, such as China, face (Zhu, Wittmann, \& Peng, 2012). Another example showed that the current state of the regulatory quality, rule of law, and corruption in Russia inhibit firm innovation (Chadee \& Roxas, 2013). In Ghana and South Africa, development of SMEs was found to be largely constrained by factors such as lack of access to appropriate technology; limited access to international markets; bad legislation, regulations and rules that impede the development of the sector; weak institutional capacity; and lack of management skills and training, and, most importantly, finance (Abor \& Quartey, 2010). Across nine emerging markets, it was found that firms may not have the capabilities required to convert their innovation inputs into innovation performance, which means that although they may have access to the necessary innovation inputs, their insufficient technological and innovation-related capabilities preclude the firms from enjoying the fruits of their innovation efforts (Back, Parboteeah, \& Nam, 2014). A recent systematic literature review focused on SMEs in developing countries confirmed that they are frequently faced with weak education systems, fragile legal systems, limited financial resources, unstable political powers, poor infrastructure, and cultural and linguistic distances, all of which are factors that hamper the diffusion of innovations (Zanello, Fu, Mohnen, \& Ventresca, 2015). Additionally, micro and small enterprises in developing countries frequently have very limited knowl- 
Petar Vrgović, Ivana Jošanov-Vrgović: Open Innovation Systems in Developing Countries: Sustainable Digital Networks and Collaboration in SMEs

edge and use of information technologies, which is a limiting factor if they strive to collaborate with external partners (Alderete, 2012; Duncombe \& Molla, 2009; Oyelaran-Oyeyinka \& Lal, 2006).

To be successful in OI, a small or medium enterprise has to possess a high level of knowledge in managing the relationship with external innovation partners, and it probably needs to invest many resources to keep the collaboration successful.

However, there is evidence that SMEs in developing countries are able to engage in innovative processes together with external partners (Xiaobao, Wei, \& Yuzhen, 2013). Some large developing countries (such as China, Brazil, and India) often accommodate large transnational companies, and here SMEs are sometimes contacted to innovate for their larger partners, and hence have no need to network with local companies; assistance received through this partnership is beneficial enough and it promotes technological innovations of these SMEs (Sudhir Kumar \& Bala Subrahmanya, 2010).

\subsection{Digital networks and collaboration}

Because it was previously shown that SMEs have interests to engage in OI, the next subject that should be investigated is how to connect with external partners One option could be that the enterprise builds a relationship with a single (larger) partner, but this approach is quite discouraging because the resources are probably still very limited, or there is a strong dependence on the partner (usually an OEM) who outsources the innovation process. Another option could be that the enterprise innovates jointly with others in some sort of network, in which all stakeholders are parts of a system that helps them obtain new or missing knowledge (van de Vrande et al., 2009).

Open innovation through network participation has become an increasingly widespread phenomenon, in which network information is found to be a critical factor in understanding how SMEs in developing countries respond to network constraints and opportunities (Xiaobao et al., 2013). These OI networks are sometimes formally organized in forms similar to clusters, whereas at other times they can be of an informal nature, based on specific projects or free networks that are based on trust and credibility (Dodourova \& Bevis, 2014); successful examples of networks that foster open innovation within complex ecosystems can often be found in "smart cities" where various subjects are connected through online communities to form innovative networks (Schaffers et al., 2011). SMEs can find these partner networks, both physical and virtual, especially useful when collecting data and insights in the early phases of innovation processes (Heger \& Boman, 2015); virtual innovation networks can produce interesting and useful IT artifacts that could be used in various steps of the innovation process (Wagenknecht, Crommelinck, Teubner, \& Weinhardt, 2017).

In developed countries, SMEs are able to selforganize in innovation virtual networks and thus make significant innovation results. These networks are found to have better performance if they have an "ideal" profile: goal and resource complementarity, fairness, reliability, trust, and network position strength; a relatively closed, focused, and consistent "business-like" networking approach, which is characterized by result orientation and professionalism, is related to high innovation performance (Pullen, Weerd-Nederhof, Groen, \& Fisscher, 2012). On another side of the spectrum, loose digital networks can be found, in which partnering is ad hoc and collaboration goes through campaigns which everyone is free to join, usually through a centralized commercial organizer or professional OI platform provider (e.g., Hyve or Exago) that establishes and manages an ideation and/or partnering platform.

However, Section 2.2 listed numerous obstacles that omit SMEs in developing countries from establishing and using these digital or virtual networks. For small business subjects in developing countries, it is hard to imagine being part of a network like this; no one has the time, knowledge, and resources to establish such connections, and poor legislation does not protect network members. In these cases, it is suggested that a network should be established and maintained by an independent intermediate that possesses knowledge and resources to keep the network alive. For example, Lee et al. (2010) proposed an intermediated network model for open innovation in SMEs in which the role of an intermediary consists of multiple activities: design a 
database to identify appropriate collaborative partners; support the formation of network ties; manage the network; provide objective feedback to all network members; and establish the culture of collaboration by promoting collaborative behavior and activities. In developing countries, it was found that this intermediary could be some form of a government agency or similar subject appointed by the authorities (Vrgovic, Vidicki, Glassman, \& Walton, 2012). Because small companies often have severely limited absorptive capacities to turn external knowledge into innovative products and services, collective research centers could even be designed to act as technology intermediaries; this happened in Belgium in the aftermath of the Second World War (Spithoven, Clarysse, \& Knockaert, 2010). Although this approach is beneficial, in these cases SMEs are relatively passive network participants that can only hope that someone else will construct and manage the network and allow them to play with others.

If SMEs in developing countries wish to create networks of their own, it is suggested that they start small, with only a handful of partners and with modest tools for collaboration. First, the partners (endusers, suppliers, research institutes, or someone else) and the desired direction of the knowledge transfer (inbound or outbound) should be clearly defined.

Second, SMEs need to understand that innovative processes have both convergent and divergent parts, and the firms need to be flexible during the innovation journey with external partners when it comes to managing different parts of the innovation process (Vrgović \& Jošanov-Vrgović, 2017). Today, there is a plethora of online tools available for idea generation, idea collection, and idea evaluation. These tools are relatively easy to set-up and intuitive to use, but what happens with the results of their use is usually the bottleneck for the SMEs, because their absorptive capacity is often limited. Therefore, in the stage of idea implementation, it is suggested that SMEs use collaboration software, which is also abundant online. Collaboration software is nothing more than a digital network with only a few nodes, which may be a good solution for SMEs in developing countries: it is more affordable and applicable than innovation management software; it is ready for use out-of-the-box; it is easily manageable; and it is intimate enough to allow collaboration partners to gain trust, which is very important for the SMEs (Török \& Tóth, 2013).

Third, in addition to financial and human resources, SMEs are also short of managerial resources and capabilities and find it difficult to engage in broad networks due to the high opportunity cost of management time. Network leadership was therefore found to be a key to driving innovation, and points to the critical importance of the IP regime and support infrastructure for realizing the full innovation potential of networks (Dodourova \& Bevis, 2014). SMEs should hence start small and with realistic expectations, and they should build and lead sustainable innovation networks organically, respecting the pace that follows the learning curve. Obstacles are significant and numerous, and steps should be taken slowly and carefully.

\section{DISCUSSION AND CONCLUSION}

Based on the previous literature, which states that external networking to acquire new or missing knowledge is an important OI activity among SMEs (van de Vrande et al., 2009), this paper explores means that SMEs in developing countries can use to achieve this. Because there are many external and internal obstacles for collaboration, the main suggestion for the SMEs is to try to collaborate slowly and with only a few partners, using the software solutions they find to be the best. There is no single solution or ideal way to achieve this, especially because developing countries significantly differ in their national cultures.

Nowadays, the availability and usability of the internet and collaboration software is much better than it was ten years ago, and even SMEs in the lowtech sector can afford to embrace networking tools. SMEs in developing countries can either join an innovation network that was designed by an intermediary body, or they can start building modest relationships with the partners they trust, slowly growing the network as their business develops. What they need to understand is that the tool itself will not lead to any innovation results. Enterprises need to have a sustainable strategy and absorptive capacity to use the newly obtained knowledge. 
Petar Vrgović, Ivana Jošanov-Vrgović: Open Innovation Systems in Developing Countries: Sustainable Digital Networks and Collaboration in SMEs

\section{EXTENDED SUMMARY / IZVLEČEK}

Mala in srednje velika podjetja (MSP) v državah v razvoju lahko pri svojih inovacijskih projektih sodelujejo z zunanjimi partnerji. Omejitve za samostojno izvajanje projektov izvirajo iz medsebojnih koristi sodelovanja $z$ drugimi subjekti. Kljub temu se mala in srednje velika podjetja $v$ državah $v$ razvoju soočajo z mnogimi ovirami, zato delovanje $v$ tem kontekstu ni enostavno. Obstaja veliko spletnih orodij, ki spodbujajo takšno sodelovanje, vendar mala in srednja podjetja v državah v razvoju le redko vedo, kako načrtovati in vzdrževati to vrsto ekosistema. Namen prispevka je pridobiti vpogled v prakso $v$ državah v razvoju, natančneje kako se soočajo z oblikovanjem in vzdrževanjem digitalnih odprtih omrežij (OI). Cilj tega prispevka je analizirati, kako mala in srednje velika podjetja $v$ državah v razvoju uspešno uporabljajo digitalna omrežja za sodelovanje z zunanjimi partnerji. Članek podaja kratek pregled sodobnih orodij za sodelovanje, ki se učinkovito uporabljajo v odprtih inovacijah (OI), ki mu sledi pregled ovir, s katerimi se srečujejo mala in srednja podjetja pri poskusu uporabe digitalnih omrežij. Nenazadnje članek vsebuje spoznanja o praksah, ki bi jih lahko ta mala in srednja podjetja uporabljala za spletno uporabo z ustreznimi orodji.

\section{REFERENCES}

Abor, J., \& Quartey, P. (2010). Issues in SME development in Ghana and South Africa. International Research Journal of Finance and Economics, 39(6), 215-228.

Alderete, M. V. (2012). Medición de las tecnologías de la información y la comunicación en empresas de servicios de Colombia. Cuadernos de Administración, 25(45).

Antikainen, M., Mäkipää, M., \& Ahonen, M. (2010). Motivating and supporting collaboration in open innovation. European Journal of Innovation Management, 13(1), 100-119.

Back, Y., Parboteeah, K. P., \& Nam, D. (2014). Innovation in emerging markets: The role of management consulting firms. Journal of International Management, 20(4), 390-405.

Brunswicker, S., \& van de Vrande, V. (2014). Exploring Open Innovation in Small and Medium-Sized Enterprises. In H. Chesbrough, W. Vanhaverbeke, \& J. West (Eds.), New Frontiers in Open Innovation. Oxford Scholarship Online.

Chadee, D., \& Roxas, B. (2013). Institutional environment, innovation capacity and firm performance in Russia. Critical Perspectives on International Business, 9(1/2), 19-39.

Chesbrough, H. (2003). Open innovation: The new imperative for creating and profiting from technology. Harvard Business Press.

Chesbrough, H. (2006). Open innovation: A new paradigm for understanding industrial innovation. In H. Chesbrough, W. Vanhaverbeke, \& J. West (Eds.), Open Innovation: Researching a New Paradigm2 (pp. 1-12). New York: Oxford University Press.
Christensen, J. F., Olesen, M. H., \& Kjær, J. S. (2005). The industrial dynamics of Open Innovation-Evidence from the transformation of consumer electronics. $R e$ search Policy, 34(10), 1533-1549.

Cooper, R. G., Edgett, S. J., \& Kleinschmidt, E. J. (2003). Best practices in product innovation: What distinguishes top performers. Ancaster, ON: Product Development Institute.

Dodourova, M., \& Bevis, K. (2014). Networking innovation in the European car industry: Does the Open Innovation model fit? Transportation Research Part A: Policy and Practice, 69, 252-271.

Duncombe, R., \& Molla, A. (2009). Formalisation of information systems in Sub-Saharan African small and medium enterprises: Case of Botswana. The African Journal of Information Systems, 1(2), 2.

Hadjimanolis, A. (1999). Barriers to innovation for SMEs in a small less developed country (Cyprus). Technovation, 19(9), 561-570. https://doi.org/http://dx.doi.org/ 10.1016/S0166-4972(99)00034-6

Heger, T., \& Boman, M. (2015). Networked foresight-The case of EIT ICT Labs. Technological Forecasting and Social Change, 101, 147-164.

Hossain, M. (2015). A review of literature on open innovation in small and medium-sized enterprises. Journal of Global Entrepreneurship Research, 5(1), 1-12.

Howes, N.R. (2001). Modern project management: successfully integrating project management knowledge areas and processes. New York: Amacom.

Hsieh, T., Lu, S., Wu, C. (2004). Statistical analysis of causes for change orders in metropolitan public works. International Journal of Project Management. 22 (8), 679-686. 
Lee, S., Park, G., Yoon, B., \& Park, J. (2010). Open innovation in SMEs-An intermediated network model. Research Policy, 39(2), 290-300. https://doi.org/ 10.1016/j.respol.2009.12.009

Massa, S., \& Testa, S. (2008). Innovation and SMEs: Misaligned perspectives and goals among entrepreneurs, academics, and policy makers. Technovation, 28(7), 393-407. https://doi.org/http://dx.doi.org/10.1016/ j.technovation.2008.01.002

Oyelaran-Oyeyinka, B., \& Lal, K. (2006). Learning new technologies by small and medium enterprises in developing countries. Technovation, 26(2), 220-231.

Parida, V., Westerberg, M., \& Frishammar, J. (2012). Inbound Open Innovation Activities in High-Tech SMEs: The Impact on Innovation Performance. Journal of Small Business Management, 50(2), 283-309. https://doi.org/10.1111/j.1540-627X.2012.00354.x

Pullen, A. J., Weerd-Nederhof, P. C., Groen, A. J., \& Fisscher, O. A. (2012). Open Innovation in Practice: Goal Complementarity and Closed NPD Networks to Explain Differences in Innovation Performance for SMEs in the Medical Devices Sector. Journal of Product Innovation Management, 29(6), 917-934. https://doi.org/10.1111/j.1540-5885.2012.00973.x

Rahman, H., \& Ramos, I. (2014). Open Innovation in SMEs: Prospects and Challenges. In J. Devos, H. van Landeghem, \& D. Deschoolmeester (Eds.), Information Systems for Small and Medium-sized Enterprises SE - 16 (pp. 313-335). Springer Berlin Heidelberg. https://doi.org/10.1007/978-3-642-38244-4_16

Schaffers, H., Komninos, N., Pallot, M., Trousse, B., Nilsson, M., \& Oliveira, A. (2011). Smart cities and the future internet: Towards cooperation frameworks for open innovation. In The future internet assembly (pp. 431-446). Springer.

Spithoven, A., Clarysse, B., \& Knockaert, M. (2010). Building absorptive capacity to organise inbound open innovation in traditional industries. Technovation, 30(2), 130-141.

Spithoven, A., Vanhaverbeke, W., \& Roijakkers, N. (2013). Open innovation practices in SMEs and large enterprises. Small Business Economics, 41(3), 537-562. https://doi.org/10.1007/s11187-012-9453-9

Sudhir Kumar, R., \& Bala Subrahmanya, M. H. (2010). Influence of subcontracting on innovation and economic performance of SMEs in Indian automobile industry. Technovation, 30(11-12), 558-569. https://doi.org/10.1016/j.technovation.2010.06.005

Török, A., \& Tóth, J. (2013). Open characters of innovation management in the Hungarian wine industry. Agricultural Economics/Zemedelska Ekonomika, 59(9). van de Vrande, V., de Jong, J. P. J., Vanhaverbeke, W., \& de Rochemont, M. (2009). Open innovation in SMEs: Trends, motives and management challenges. Technovation, 29(6-7), 423-437. https://doi.org/10.1016/ j.technovation.2008.10.001

Vanhaverbeke, W., Chesbrough, H., \& West, J. (2014). Surfing the new wave of open innovation research. In H. Chesbrough, W. Vanhaverbeke, \& J. West (Eds.), New frontiers in open innovation (pp. 281-294). Oxford: Oxford University Press.

Vrgović, P., \& Jošanov-Vrgović, I. (2017). Crowdsourcing user solutions: which questions should companies ask to elicit the most ideas from its users? Innovation, 19(4), 452-462. https://doi.org/10.1080/ 14479338.2017.1356618

Vrgovic, P., Vidicki, P., Glassman, B., \& Walton, A. (2012). Open innovation for SMEs in developing countries-an intermediated communication network model for collaboration beyond obstacles. Innovation: Management, Policy \& Practice, 14(3), 290-302.

Vrgović, P., Vidicki, P., \& Šenk, V. (2013). Employees' Communication Patterns in Unorganized Idea-sharing Activities. International Journal of Industrial Engineering and Management, 4(1), 11-18.

Wagenknecht, T., Crommelinck, J., Teubner, T., \& Weinhardt, C. (2017). Ideate. Collaborate. Repeat. A Research Agenda for Idea Generation, Collaboration and Evaluation in Open Innovation. In J. M. Leimeister \& W. Brenner (Eds.), Proceedings der 13. Internationalen Tagung Wirtschaftsinformatik (WI 2017) (pp. 942956). St. Gallen, Switzerland.

West, J., \& Bogers, M. (2014). Leveraging External Sources of Innovation: A Review of Research on Open Innovation. Journal of Product Innovation Management, 31(4), 814-831. https://doi.org/10.1111/jpim.12125

Xiaobao, P., Wei, S., \& Yuzhen, D. (2013). Framework of open innovation in SMEs in an emerging economy: firm characteristics, network openness, and network information. International Journal of Technology Management, 62(2), 223-250. https://doi.org/ 10.1504/IJTM.2013.055142

Zanello, G., Fu, X., Mohnen, P., \& Ventresca, M. (2015). The creation and diffusion of innovation in developing countries: a systematic literature review. Journal of Economic Surveys, 30(5), 884-912. https://doi.org/ 10.1111/joes.12126

Zhu, Y., Wittmann, X., \& Peng, M. W. (2012). Institutionbased barriers to innovation in SMEs in China. Asia Pacific Journal of Management, 29(4), 1131-1142. 